\title{
Nobody wins the victory taboo in just war theory
}

\section{Cian O’Driscoll}

To cite this article: Cian O'Driscoll (2019) Nobody wins the victory taboo in just war theory, Journal of Strategic Studies, 42:7, 901-919, DOI: 10.1080/01402390.2019.1588118

To link to this article: https://doi.org/10.1080/01402390.2019.1588118
(c) 2019 The Author(s). Published by Informa UK Limited, trading as Taylor \& Francis Group.

曲 Published online: 21 Mar 2019.

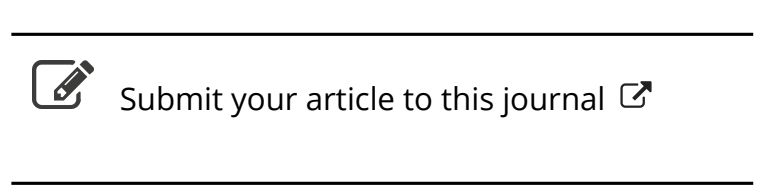

LII Article views: 2314

Q View related articles $\asymp$

View Crossmark data $\asymp$ 


\title{
Nobody wins the victory taboo in just war theory
}

\author{
Cian O'Driscoll
}

School of Social and Political Science, University of Glasgow, Glasgow, UK

\begin{abstract}
This article examines how scholars of the just war tradition think about the ethical dilemmas that arise in the endgame phase of modern warfare. In particular, it focuses upon their reticence to engage the idiom of 'victory'. Why, it asks, have scholars been so reluctant to talk about what it means to 'win' a just war? It contends that, while just war scholars may have good reason to be sceptical about 'victory', engaging it would grant them a more direct view of the critical potentialities, but also the limitations, of just war reasoning.
\end{abstract}

KEYWORDS Just war; VICTORY; jus post bellum; tradition; ethics of war

\section{Introduction}

How do wars end? There is an influential school of thought which contends that while wars can be concluded in a myriad of ways, they are highly unlikely to result in the outcome that most people will intuitively think of first-a decisive victory for one side, and an emphatic defeat for the other. ${ }^{1}$ Scholars associated with this approach contend that wars are no longer likely to conclude with a clear winner and loser, but can instead be expected to drag on in a ragged fashion to the point where it is difficult to discern not just who won, but whether the war is even over. ${ }^{2}$ The notion of victory, they conclude, is anachronistic and of little salience to the realities of contemporary armed conflict. Events in Iraq, Afghanistan, Libya and elsewhere lend credence to this perspective. ${ }^{3}$ This point of view is, however, at odds with the enduring ubiquity of victory in elite discourse. While military historians and strategists dismiss the idea of victory as hopelessly jejune, political and military leaders continue to invoke it frequently and with just as much enthusiasm as ever. ${ }^{4}$

CONTACT Cian O'Driscoll Cian.odriscoll@glasgow.ac.uk E University of Glasgow, Glasgow, UK

${ }^{1}$ The key statement of this position is arguably: Dominic Tierney, The Right Way to Lose a War: America in an Age of Unwinnable Conflicts (New York: Little, Brown and Company 2015).

2For example: Robert Mandel, 'Defining Postwar Victory', in Jan Angstrom and Isabelle Duvesteyn (eds.), Understanding Victory and Defeat in Contemporary War (Abingdon: Routledge 2007), 18.

${ }^{3}$ See: Gideon Rose, How Wars End: Why We Always Fight the Last Battle (New York: Simon \& Schuster 2011).

${ }^{4}$ On the current ubiquity of victory talk in international relations: Cian O'Driscoll and Andrew R. Hom, 'Introduction', in Andrew R. Hom, Cian O'Driscoll, and Kurt Mills (eds.), Moral Victories: The Ethics of Winning Wars (Oxford: Oxford University Press 2017), 2-3. 
My intention in this essay is to take the idea of victory seriously, and, following this, to examine how, if at all, it fits within the predominant Western framework for thinking about the rights and wrongs of warfare, the just war tradition. My argument, which I will develop over four sections, is that, although scholars of the just war tradition appear to have good reason for avoiding the idiom of victory, their failure to engage with it blunts the tradition's critical edge.

Section One introduces the just war tradition. Section Two details the reluctance of just war scholars to grapple with the notion of victory. Section Three examines the reasons behind this evasion, noting certain problems that pertain to the general concept of victory, and others that are specific to its relation to the ideal of just war. Squaring the circle, Section Four proffers an argument for why, despite all the apparent problems it raises, scholars of the just war tradition should engage the concept of victory. Finally, bringing all of this together in the conclusion, I will make the case for both why scholars should never forget that just war is just war, and why this is a matter of some importance for anyone with an interest in War Studies.

\section{The just war tradition}

Just war is commonly associated today with Michael Walzer's classic 1977 text, Just and Unjust Wars. ${ }^{5}$ This book advances three main arguments. The first, directed against those who profess that the law is silent when arms are drawn, is that war is not a realm of necessity and therefore moral anarchy. ${ }^{6}$ Instead it is a social activity, and the actions of those who partake in it are rightly amenable to ethical scrutiny and evaluation. The second argument is that the norms that delimit the practice of warfare are crystallised in what Walzer refers to as 'just war theory'. According to Walzer, just war theory comprises two modes of judgement. 'War is always judged twice, first with reference to the reasons states have for fighting, secondly with reference to the means they adopt', he writes. 'The first kind of judgement is adjectival in character: we say that a particular war is just or unjust. The second is adverbial: we say that the war is being fought justly or unjustly., ${ }^{7}$ The third argument is that the norms that are embedded in just war theory, and which form the substance of both modes of judgement, require revision if they are to accord with the values attested by the signatories to the UN Charter and upon which the post-1945 international order rests.

Walzer was not, of course, the originator of just war theory. Rather, he was drawing on a tradition of inquiry that can be traced back at least as far as the

\footnotetext{
${ }^{5}$ Michael Walzer, Just and Unjust Wars: A Moral Argument with Historical Illustrations - 5th edition (New York: Basic Books 2015).

${ }^{6}$ Walzer, Just and Unjust Wars, 3.

${ }^{7}$ Walzer, Just and Unjust Wars, 21.
} 
fourth century CE political theology of Saint Augustine, and which later involved such luminaries as Thomas Aquinas and Hugo Grotius, among others. ${ }^{8}$ At the heart of this tradition is the dual conviction that while the use of military force by political communities may be justified in certain circumstances, it must be subject to moral regulation. These convictions are usually bracketed under two Latinate headings that correspond to the two modes of judgement identified by Walzer. The jus ad bellum comprises the categories of analysis that people consult when seeking to determine what if any conditions might justify the resort to war on the part of a community. It thus encompasses the familiar concepts of just cause, proper authority, right intention, proportionality and last resort. The jus in bello aggregates the precepts that limit the conduct of war. These centre on the principles of discrimination and proportionality. While there is a healthy consensus among scholars regarding the centrality of these categories of analysis, they routinely disagree over how they should be defined and weighted relative to one another.

Although the tradition was not so long ago an obscure hobbyhorse kept alive only by Catholic seminary schools and historians of international law, it has experienced a revival in recent years. ${ }^{9}$ Academic interest in the just war tradition has mushroomed since the publication of Just and Unjust Wars in 1977, with an upsurge in the number of universities teaching the subject, more people writing books and articles about it and the emergence of a specialist periodical, the Journal of Military Ethics, dedicated to servicing this new cottage industry. Alongside this, the just war tradition has become a staple on curricula at military academies the world over, and its precepts written into military codes and strategic doctrines. ${ }^{10}$ Most interestingly, however, its concepts and terminology have become increasingly prominent in the speeches and statements of military and political leaders on the topic of war. President Obama's Nobel Peace Prize Address is an obvious example of this phenomenon, but it is not unique to him; President George W. Bush and his predecessors were also no strangers to the just war idiom. ${ }^{11}$

\section{Conspicuous by its absence}

As the literature on just war has grown in recent years, so too has the range of topics it has addressed. Every nook and cranny of the various jus ad

\footnotetext{
${ }^{8}$ The origins of the tradition are disputed. Rory Cox, 'Expanding the History of the Just War: The Ethics of War in Ancient Egypt', International Studies Quarterly 61/2 (2017), 371-84. On the development of the tradition: Daniel Brunstetter and Cian O'Driscoll (eds.), Just War Thinkers: From Cicero to the 21st Century (Abingdon: Routledge 2017).

${ }^{9}$ Michael Walzer, 'The Triumph of Just War Theory (and the Dangers of Success)', in Arguing About War (New Haven, CT: Yale University Press 2003), 3-22.

${ }^{10}$ Paul Robinson, Nigel de Lee, and Don Carrick (eds.), Ethics Education in the Military (Burlington, VT: Ashgate 2008).

${ }^{11}$ See: Mark Totten, First Strike: America, Terrorism, and Moral Tradition (New Haven: Yale University Press 2010), 80-83.
} 
bellum and jus in bello categories have been explored, and they have also been extended to address emergent issues in international relations as well as new military technologies and ways of waging war. Books and articles have recently been published on, among other things, the ethics of nonviolent ways of conducting war, the use of force short of war, drone warfare, the ethics of espionage, the limits of anticipatory defence, the continuing utility of sovereignty as a baseline for moral reasoning about war, the ethical challenges posed by the use of robotics and artificial intelligence in armed conflict and the implications of new conceptions of spatiality for both jus ad bellum and jus in bello categories. ${ }^{12}$ One topic that is conspicuous by its absence is, however, victory.

At this point, scholars familiar with just war theory may query this claim by pointing to two issues that have so far been overlooked. The first is the category of 'reasonable chance of success', which many scholars identify as an integral component of the jus ad bellum framework. ${ }^{13}$ It stipulates that the use of force should not be employed, even where it is otherwise justified, in situations where it is likely to end in failure. As such it serves a 'prudential' function, obliging communities to refrain from the pursuit of just but futile causes. ${ }^{14}$ The issue here is that the idiom of victory is subsumed within a general 'prudential calculation of the likelihood that the means used will bring the justified ends sought. ${ }^{15}$ A vague emphasis on utilitarian calculations cast in the generic language of success, which is neither defined nor interrogated, thus forecloses more specific considerations pertaining to the termination of war. Not only, then, does the principle of 'reasonable chance of success' tell us little about victory, it replaces it with platitudes.

The second issue requires more attention. It relates to the jus post bellum framework. Conceived as a stand-alone category, the jus post bellum is a recent addition to just war thinking. It was first proposed by Michael $J$. Schuck in a 1994 essay, 'When the Shooting Stops: Missing Elements in Just War Theory', published in The Christian Century. Disgusted by the triumphalism displayed by the United States in the wake of the 1991 Gulf War-and

\footnotetext{
${ }^{12}$ Some notable recent publications include: Michael L. Gross and Tamar Meisels (eds.), Soft War: The Ethics of Unarmed Conflict (Cambridge: Cambridge University Press, 2017); George Lucas, Ethics and Cyber Warfare: The Quest for Responsible Security in the Age of Digital Warfare (Oxford: Oxford University Press 2017); James Pattison, Just and Unjust Alternatives to War (Oxford: Oxford University Press 2018); and Amy Eckert, Outsourcing War: The Just War Tradition in the Age of Military Privatization (New York: Cornell University Press 2015). This list is indicative rather than exhaustive. It is intended to offer a sense of the wide range of topics just war scholars have tackled in recent years.

${ }^{13}$ Colin Gray and Keith Payne present it as 'one of the six guidelines for the use of force provided by the "just war" doctrine'. Colin S. Gray and Keith Payne, 'Victory is Possible', Foreign Policy 39 (1980), 16.

${ }^{14}$ James Turner Johnson, Morality and Contemporary Warfare (New Haven: Yale University Press 1999), 34.

${ }^{15}$ Johnson, Morality and Contemporary Warfare, 29.
} 
especially the jingoistic victory parade that members of the military top brass (including General Norman Schwarzkopf) celebrated on Main Street, Disneyland-Schuck argued that just war theory, as it then stood, offered no guidance for how communities should comport themselves in the aftermath of war. He proposed that a new pole of just war reasoning, which he christened the jus post bellum, should be formulated to meet this need. ${ }^{16}$

Schuck's proposition received a warm response. A number of leading scholars, including Alex J. Bellamy, Gary Bass, Brian Orend, Larry May, and Eric Patterson, endorsed it, and set about acting upon it. ${ }^{17}$ Victory was, quite literally, the pivot for these formulations. As May framed it, for instance, the key question for jus post bellum theorists is 'what difference should there be between victors and vanquished in terms of post-war responsibilities? ${ }^{18}$ On a similar note, Bellamy submitted that one could approach the task of jus post bellum theorising with either a minimalist or maximalist approach, a distinction that turns on whether one assigns minor or extensive post-war responsibilities to the victors for societies they have vanquished in combat. $^{19}$

Victory, then, functions as a threshold for jus post bellum deliberations. Herein lies the rub. Victory is assumed as a point of departure rather than interrogated by jus post bellum theorists. It is taken as a premise rather than a substantive issue or matter for inquiry. ${ }^{20}$ This is reflected in a line from Michael Walzer's most recent essay on the topic: 'I am going to assume the victory of just warriors, and ask what their responsibilities are after victory. ${ }^{21}$ The explanation for this is of course that the jus post bellum has not in fact evolved as a framework designed to shed light on what we might term the ethics of victory. In actual fact, it has evolved as a guide for reflecting upon the rights and duties that victors obtain after victory has been attained by one side over the other and the transition to peace has already begun. ${ }^{22}$

\footnotetext{
${ }^{16}$ Michael J. Schuck, 'When the Shooting Stops: Missing Elements in Just War Theory', Christian Century (26 October 1994), 982-83.

${ }^{17}$ Alex J. Bellamy, 'The Responsibilities of Victory: Jus Post Bellum and the Just War', Review of International Studies 34 (2008), 601-25; Gary Bass, 'Jus Post Bellum', Philosophy \& Public Affairs 32/4 (2004), 384-412; Brian Orend, 'Jus Post Bellum', Journal of Social Philosophy 31/1 (2000), 117-37; Larry May, After War Ends: A Philosophical Perspective (Cambridge: Cambridge University Press 2012); Eric D. Patterson (ed.), Ethics Beyond War's End (Washington, DC: Georgetown University Press 2012); and Mark J. Allman and Tobias L. Winwright, After the Smoke Clears: The Just War Tradition and Post War Justice (Maryknoll, NY: Orbis 2010).

${ }^{18}$ May, After War Ends, 1.

${ }^{19}$ Bellamy, 'The Responsibilities of Victory', 602.

${ }^{20}$ Cian O'Driscoll, 'At All Costs and in Spite of All Terror? The Victory of Just War', Review of International Studies 41 (2015), 805-08. Also: Mona Fixdal, Just Peace: How Wars Should End (New York: Palgrave 2012), 17.

${ }^{21}$ Michael Walzer, 'The Aftermath of War: Reflections on Jus Post Bellum', in Eric D. Patterson (ed.), Ethics Beyond War's End (Washington, DC: Georgetown University Press 2012), 37. Emphasis added.

${ }^{22}$ David Rodin, 'Two Emerging Issues of Jus Post Bellum: War Termination and the Liabilities of Soldiers for Crimes of Aggression', in Carsten Stahn and Jan K. Kleffner (eds.), Jus Post Bellum: Towards a Law of Transition from Conflict to Peace (The Hague: TMC Asser Press 2008), 53-77.
} 
There have recently been some attempts to correct for the omission of victory from the jus post bellum framework, but there is as yet no systematic body of work on the matter. ${ }^{23}$

When one sets the jus post bellum aside and turns to more general contemporary writings on just war, the situation is compounded. Victory is even further outside the frame. Indeed, it hardly features at all in most just war texts, even when scholars are ostensibly discussing how wars end. Walzer is a case in point. He alludes to victory on several occasions in Just and Unjust Wars, and while his remarks are in each case intriguing, they are also minimal and not developed. Early in the text, for instance, he observes that the imperative to achieve victory in a just war can, if unchecked, militate against an army's commitment to waging war in a just manner. As he puts it, the quest for 'moral decency in battle and victory in war' are at crossed purposes. ${ }^{24}$ Later, he notes that the intended end of any just war must be victory, but then immediately concedes that it can be difficult to discern what this means in practical terms. 'A just war is one that is morally urgent to win, and a soldier who dies in a just war does not die in vain ... But if it is sometimes urgent to win, it is not always clear what winning is. ${ }^{\prime 25}$ These remarks are, to be sure, food for thought, but Walzer, regrettably, does not expand on them.

Yet in mentioning victory in any kind of substantive sense, Walzer still goes far further than most contemporary just war scholars. A review of the key works in the field reveals that standard practice is to refer to the termination of war in terms of either a temporal break - the 'ending' or cessation of war-or the values for which it is fought, typically construed in terms of a balance between justice, peace, and order. Victory seldom features in such formulations. It is conspicuous only by its absence. The opening statement of Mona Fixdal's otherwise excellent book, Just Peace: How Wars Should End, is typical in this regard:

How should wars end? ... I hold that any morally acceptable outcome to a war must strike a balance between the goals of justice and of peace. The war should end in a 'better state of peace', a peace that is more just and stabler than that which held before it began. ${ }^{26}$

Eric Patterson similarly sets out the desired endpoint of a just war in terms of a harmony between order, justice and conciliation. ${ }^{27}$ The point in both cases is not necessarily that their approach is wrong, nor even that they

\footnotetext{
${ }^{23}$ Four contributions stand out: Janina Dill (ed.), 'Symposium on Ending Wars', Ethics 125/3 (2015), 627780; Beatrice Heuser, 'Victory, Peace, and Justice: The Neglected Trinity', Joint Forces Quarterly 69 (2013), 1-7; Gabriella Blum, 'The Fog of Victory', European Journal of International Law 24/1 (2013), 391-421; and Hom, O'Driscoll, and Mills, Moral Victories.

${ }^{24}$ Walzer, Just and Unjust Wars, 48; also 31-32.

${ }^{25}$ Walzer, Just and Unjust Wars, 110.

${ }^{26}$ Fixdal, Just Peace, 1. Fixdal (fn.1) attributes the phrase 'better state of peace' to Basil Liddell Hart and Michael Walzer.

${ }^{27}$ Eric D. Patterson, Ending Wars Well: Order, Justice, and Conciliation in Contemporary Post-Conflict (New Haven, CT: Yale University Press 2012).
} 
have selected the wrong values to emphasise. It is simply that victory is nowhere to be found in either formulation. It has been deftly and effectively circumnavigated. The purpose of this article is to consider whether this is the right strategy. Towards this end, it will consider the possibly that these approaches might be enriched by bringing them into dialogue with the concept of victory.

\section{Why is victory a bad word?}

Before turning to why it would be a good thing for just war scholars to engage the concept of victory, it is first necessary to devote a few words to thinking about why they have not done so already. Why, in other words, has victory become a taboo subject for just war scholars? A brief discussion of a landmark publication in the field provides a way into this question.

Larry May's 2012 monograph, After War Ends: A Philosophical Perspective, is the book in question. ${ }^{28}$ As the title suggests, After War Ends comprises a philosophical engagement with the jus post bellum component of just war reasoning. It is the most comprehensive monograph available on ethics at the end of war today and is a very impressive, high-quality piece of work. What I would like to focus on here, however, is how the text is framed. The scope of the book-and indeed of the jus post bellum, as introduced by May-is defined by reference to a temporal demarcation: after war ends. This approach raises several red flags. Are terms like 'before', 'during' and 'after' helpful when it comes to speaking about war? Or is their tidy sequencing out of synch with the messiness of what they purport to describe? And how could one tell when or even whether a war had truly ended? It seems to me at least that this is a very sandy bottom in which to anchor jus post bellum analysis.

Would it not be a better idea, one wonders, to peg jus post bellum analysis more firmly to the idea of victory, rather than that of the ending of war? This would have the positive effect of tying jus post bellum reasoning to the strategic rationale of war-fighting while also (one could hope) avoiding the kind of spongy thinking that a reliance on terms such as 'after' encourages. Scholars of the just war tradition have been very resistant to this proposal. The concept of victory, they argued, has no proper place in just war thinking. The reasons they gave for this are instructive, and can be helpfully lumped into two brackets, each of which maps onto a broader set of concerns. Together they tell us something about why just war scholars have hitherto neglected the concept of victory.

The first bracket encompassed problems that are inherent to the concept of victory itself. These problems stemmed from the fact that victory turns out to be just as spongy a concept as 'after', and equally difficult to define. Interestingly, this observation is not merely an outsider's prejudice, but is

\footnotetext{
${ }^{28}$ See fn. 17.
} 
shared by those who have spent time studying and writing about victory. Thus Robert Mandel, the author of The Meaning of Military Victory, describes it as a 'fuzzy, contentious, and emotionally charged' concept, while Richard Hobbs variously describes it as an 'elusive phantom' and a 'mysterious and enticing shadow'. ${ }^{29}$ The suggestion in both cases is that victory is an inherently nebulous concept that eludes easy definition. ${ }^{30}$ While strategists might follow Carl von Clausewitz in insisting that victory is achieved by thwarting one's opponents in battle and imposing one's will upon them, it is not clear exactly what it signifies, or how one would identify whether or when it has been achieved in practice. ${ }^{31}$

The case of Iraq is an illuminating reference point. Allied forces secured a decisive military victory over the Iraqi Army in the 1991 Gulf War, but the survival of Saddam Hussein's Ba'athist regime and its subsequent refusal to accept the verdict of battle led observers to discount this victory as 'hollow'. ${ }^{32}$ Twelve years later, when a US-led coalition invaded Iraq, ousted Hussein, and seized control of Baghdad, it appeared to many that the promise of victory, frustrated in 1991, had finally been realised. The sight of President George W. Bush aboard the U.S.S. Abraham Lincoln declaring 'Mission accomplished' supported this view. ${ }^{33}$ Yet fighting continued for many years after, and the fate of Iraq is still uncertain today-facts that led many people to query whether victory had ever been achieved in the first place. The words of Phil Klay, a short story writer who served in Iraq during the surge, capture something of this ambiguity: 'Success was a matter of perspective. In Iraq it had to be. There was no Omaha Beach, no Vicksburg Campaign, not even an Alamo to signal a clear defeat. The closest we'd come were those toppled Saddam statues, but that was years ago. ${ }^{34}$

This belies that there is no obvious way of discerning whether and when victory has been won in wars like that in Iraq. ${ }^{35}$ There is no consensus, for

\footnotetext{
${ }^{29}$ Robert Mandel, The Meaning of Military Victory (Boulder, CO: Lynne Rienner 2006), 13; and Richard Hobbs, The Myth of Victory: What is Victory in War? (Boulder, CO: Westview 1979), xvi, 2.

${ }^{30}$ This impression is supported by the fact that attempts to define victory frequently descend into typologies that distinguish different kinds or levels of victory (e.g., tactical, strategic, political, military, etc.). See: William C. Martel, Victory in War: Foundations of Modern Military Policy (Cambridge: Cambridge University Press 2007); and Brian Bond, The Pursuit of Victory: From Napoleon to Saddam Hussein (Oxford: Oxford University Press 1996).

${ }^{31}$ Carl von Clausewitz, On War, ed. by Michael Howard and Peter Paret (Princeton: Princeton University Press 1989), 1.

${ }^{32}$ Jeffrey Record, Hollow Victory: A Contrary View of the Gulf War (Washington, DC: Brassey's 1993).

${ }^{33}$ President George W. Bush, 'President Bush Announces Major Combat Operations in Iraq Have Ended, 1 May 2003'. Available at: https://georgewbush-whitehouse.archives.gov/news/releases/2003/05/ 20030501-15.html. Accessed: 16 July 2017.

${ }^{34}$ Phil Klay, Redeployment (New York: Penguin, 2014), p. 77.

${ }^{35}$ On this: Dominic P. Johnson and Dominic Tierney, Failing to Win: Perceptions of Victory and Defeat in International Politics (Cambridge MA: Harvard University Press, 2006); Jan Angstrom, 'The United States Perspective on Victory in the War on Terrorism', in Jan Angstrom and Isabelle Duvesteyn (eds.), Understanding Victory and Defeat in Contemporary War (Abingdon, Routledge, 2007): 94-113; and General Tommy Franks, 'The Meaning of Victory: A Conversation with Tommy Franks', The National Interest 86 (November 2006): 8.
} 
instance, over the right metrics to employ in this kind of determination. At various times in the past, armies have used different markers to gauge whether or not victory had been won. Greek poleis equated victory with driving the enemy army from the battlefield, while later societies associated it with, among other things, the annexation of territory, the capture of the adversary's capital city, a superior body-count, regime change and the winning of hearts and minds. ${ }^{36}$ The point to glean from this is that victory is just as difficult to identify in concrete terms as it is to define in the abstract.

Going beyond this, some scholars claim that the problem is not simply that victory is difficult to define or identify in practice, it is that is not a realistic outcome in contemporary armed conflict. The nature of modern warfare is not amenable to clear-cut endings, they argue, but instead tends to produce drawn-out endgames. ${ }^{37}$ Russell Weigley is the main exponent of this view. He contends that, except for the period bookended by the battles of Breitenfeld and Waterloo, wars have seldom generated emphatic victories. ${ }^{38}$ Rather, they grind on without anybody ever actually winning. To paraphrase Officer Pryzbylewski from the critically acclaimed HBO television series, The Wire: Nobody wins, it's just that one side loses more slowly than the other. The development of modern ways of waging war, and the advent of the War on Terror, have compounded this problem. ${ }^{39}$ It is hard to win a decisive victory when wars are configured in such a way that they lack a clearly demarcated battlefield and are structured, not around the quest for pitched combat, but around strategic doctrines like the Israeli Defence Force's commitment to 'mowing the lawn'. ${ }^{40}$

The second bracket included problems pertaining to the appropriateness of using the term victory in relation to just war. The concern here was that victory is a retrograde concept that evokes forms of triumphalism and adversarialism that are at odds with the ethos of the just war tradition. According to this way of thinking, appeals to victory engender a crude win-at-all-costs mentality that undercuts the premium just war thinking places on moderation and restraint. ${ }^{41}$ Prime Minister Winston

\footnotetext{
${ }^{36}$ On this point: Leo J. Blanken, Hy Rothstein, and Jason J. Lepore (eds.), Assessing War: The Challenge of Measuring Success and Failure (Washington DC: Georgetown University Press, 2015).

${ }^{37}$ Tierney, The Right Way to Lose a War; Michael Mandelbaum, Mission Failure: America and the World in the Post-Cold War Era (Oxford: Oxford University Press, 2016).

${ }^{38}$ Russell F. Weigley, The Age of Battles: The Quest for Decisive Warfare from Breitenfeld to Waterloo (London: Pimlico, 1991).

${ }^{39}$ As General David Petraues remarked of the global war against Al Qaeda, 'this is not the sort of struggle where you take a hill, plant the flag, and go home with a victory parade.' Mark Tran, 'General David Petraeus Warns of Long Struggle Ahead for US in Iraq', Guardian, 11 September 2008. Available at: https://www.theguardian.com/world/2008/sep/11/iraq.usa. Accessed: 16 July 2017.

${ }^{40}$ Efraim Inbar and Eitan Shamir, "'Mowing the Grass": Israel's Strategy for Protracted Intractable Conflict', Journal of Strategic Studies 37/1 (2014), 65-90.

${ }^{41}$ On this point: Walzer, Just and Unjust Wars, 47-48; also: Augustine, City of God against the Pagans, ed. by R. W. Dyson (Cambridge: Cambridge University Press 1998), 109-13; 118-23. For analysis: Philip Wynn, Augustine on War and Military Service (Minneapolis: Fortress Press 2013), 265-77.
} 
Churchill provided an example of this in a speech on Allied war objectives delivered to the House of Commons in May 1940: 'What is our aim? I can answer in one word: victory - victory, victory at all costs, victory in spite of all terror; victory however long and hard the road may be; for without victory, there is no survival.' ${ }^{42}$ The situation in which Churchill's United Kingdom found itself was not unique. It is not unusual for societies waging ostensibly just wars to find themselves between a rock and hard place, whereby they and their just cause stand to be defeated unless they abandon customary jus in bello restraints and learn to fight dirty. The choice in such instances is between winning a just war and waging it justly; it is difficult, it seems, to do both. ${ }^{43}$

References to victory also, it is claimed, appear callous and insensitive when applied to modern war. How can it be proper to speak about winning, the argument goes, when the issue at hand is mechanised slaughter? As Kenneth Waltz put it: 'Asking who won a given war, someone has said, is like asking who won the San Francisco earthquake. ... In wars there is no victory but only varying degrees of defeat. ${ }^{44}$ Aristide Briand similarly observed: 'In modern war there is no victor. Defeat reaches out its heavy hand to the uttermost corners of the earth, and lays its burdens on victor and vanquished alike. ${ }^{45}$ Indeed, even Churchill, who (see above) had committed the UK to pursue victory at all costs, later conceded that the outcome of the war exposed the hollowness of such talk: 'Both sides, victors, and vanquished, were ruined. ${ }^{46}$ The inference in each case is that modern war, whether just or unjust, is sufficiently ghastly in terms of its destructiveness that the prospect of ever 'winning' it rings hollow. ${ }^{47}$ As it is articulated in Spoils, a recent novel that tackles the 2003 Iraq War, 'even if you win, you lose. ${ }^{48}$ It was precisely this point that Michael Schuck, provoked by the sight of generals celebrating the tragedy of the Gulf War as if it were a triumph, wished to make when he initially proposed the jus post bellum framework.

\footnotetext{
${ }^{42}$ Quoted in: Bond, The Pursuit of Victory, 142.

${ }^{43}$ Andrew Fiala has expressed this idea in very simple terms: 'There is an irresolvable tension between the demands of morality and the need to win.' Andrew Fiala, The Just War Myth: The Moral Illusions of War (Lanham, MD: Rowman \& Littlefield 2008), 6.

${ }^{44}$ Kenneth Waltz, Man, the State and War: A Theoretical Analysis (New York: Columbia University Press 2001), 1.

${ }^{45}$ Quoted in: Hobbs, The Myth of Victory, 477.

${ }^{46}$ Winston Churchill, The World Crisis, Volume V: The Unknown War (London: Bloomsbury 2015), 1.

${ }^{47}$ There is an interview with Bao Ninh, a veteran of the North Vietnamese Army, in the 2017 Ken Burns and Lynn Novick documentary, The Vietnam War, that bears reference here. 'People sing about victory ... They're wrong. Who won and who lost is not a question. In war, no one wins or loses. There is only destruction.' Quoted in: Christopher J. Finlay, Is Just War Possible? (Cambridge: Polity 2018), 55.

${ }^{48}$ Brian van Reet, Spoils (London: Jonathan Cape 2017), 199.
} 


\section{No substitute for victory?}

The arguments against victory are, it would appear, compelling. They force one to think twice about both the utility and aptness of speaking about modern war in terms of 'winning'. Yet I think there is also much that these arguments miss. I want to focus here on three important and closely related matters that, when taken seriously, put a very different complexion on matters.

The first matter bears on the role that victory plays in how we typically tend to think about war. While international lawyers may prefer to address war in terms of different sequential stages (i.e., before, during and after) that correspond to different bodies of law, pundits and practitioners alike commonly associate it with the quest for victory. As General Douglas MacArthur famously put it, 'War's very object is victory ... In war there is no substitute for victory. ${ }^{49}$ Variations on this theme have been sounded by figures from Aristotle and Sun Tzu to Presidents George W. Bush and Donald Trump..$^{50}$ It has also been enshrined in strategic thinking, most notably in the PowellWeinberger doctrine. ${ }^{51}$ War poets from Robert Southey ('After Blenheim') to Wilfred Owen ('Smile, Smile, Smile') have also echoed it, and it has even been cast in stone in the motto carved above the entrance to France's most famous military academy, Saint Cyr. ${ }^{52}$ It is also expressed in no uncertain terms by the chief protagonist in Spoils, the Iraq War novel mentioned earlier. 'We should play to win', Private Cassandra, the protagonist, tells her commanding officer. ${ }^{53}$ This matters insofar as it suggests that when proponents of just war discourse avoid the language of victory, they distance themselves from how the people who command and wage wars think about them. This has implications for the ability of those same just war scholars to speak truth to power.

\footnotetext{
${ }^{49}$ General Douglas MacArthur, 'Farewell Address to Congress, 19 April 1951'. Available at: http://www. americanrhetoric.com/speeches/douglasmacarthurfarewelladdress.htm. Accessed: 16 July 2017.

${ }^{50}$ Aristotle, Nicomachean Ethics, trans. by Harris Rackham (London: Wordsworth Classics 1996), 3; Marcus Tullius Cicero, The Republic and The Laws, trans. by Niall Rudd (Oxford: Oxford University Press 1998), 83; Sun Tzu is quoted in: Mark R. McNeilly, Sun Tzu and the Art of Modern Warfare (Oxford: Oxford University Press 2015), 16; Bush is quoted in: Angstrom, 'The United States Perspective on Victory', 98; and Trump is quoted in: Andrew R. Hom and Cian O'Driscoll, 'Can't Lose for Winning: Victory in the Trump Presidency', The Disorder of Things Blogspot, 24 January 2017. Available at: https://thedisorderofthings.com/2017/01/24/cant-lose-for-winning-victory-in-the-trumppresidency/. Accessed: 16 July 2017.

${ }^{51}$ Caspar Weinberger, 'The Uses of Military Power'. Available at: http://www.pbs.org/wgbh/pages/front line/shows/military/force/weinberger.html. Accessed: 28 May 2015.

${ }^{52}$ John I. Alger, The Quest for Victory: The History of the Principles of War (Westport, CT: Greenwood Press 1982), 173. The remarks of Sebastian Junger, a journalist who spent 15 months embedded with a US platoon at a remote outpost in Afghanistan, are also worth noting: 'Much of modern military tactics is geared toward maneuvering the enemy into a position where they can essentially be massacred from safety. It sounds dishonourable only if you imagine that modern war is about honour; it's not. It's about winning'. Sebastian Junger, War (New York: Twelve 2011), 140.

${ }^{53}$ Van Reet, Spoils, 42.
} 
There is also a case to be a made that some level of engagement with the language of victory might remind scholars that 'just war is also just war'. ${ }^{54}$ Put more plainly, it would check the growing tendency to sanitise just war by speaking about it in terms that obscure its brutish realities. ${ }^{55}$ Just wars are strategically directed violent enterprises that produce winners and losers; it would not be a bad thing for people to remember this. Not only would it refresh them of the stakes, it would also perhaps have the additional benefit of encouraging just war scholars to factor the strategic dimensions of warfare into their deliberations. So even if it is beset with difficulties, there are good pragmatic reasons why just war scholars should engage the language of victory.

The second matter is really an extension of the first. It speaks to the role that the concept of victory can play in focusing just war scholars on the utility of warfare, that is to say, on the good that it stands to accomplish in any given instance offset against the blood and treasure it is likely to cost. The words of two very different thinkers on war provide guidance here. We start with Clausewitz, who declared that no one ought to start a war without first being clear about what victory would comprise and how it could be obtained..$^{56}$ And we move from there to the sixteenth century humanist, Erasmus of Rotterdam, and in particular the advice he offered to Christian princes tasked with deciding whether or not to take their kingdoms to war. 'Let him apply just a little reason to the problem', Erasmus counselled, by 'counting up the true cost of the war and deciding whether the object he seeks to achieve by it is worth that much, even if he were certain of victory, which does not always favour even the best of causes. ${ }^{157}$ Combining these sentiments, we arrive at the idea that victory can serve as a focal concept for thinking about what exactly we hope or expect a just war to deliver-and at what price.

The third matter reverses the lens by providing a framework for scholars to think, not just about the costs of victory, but about the rewards that properly follow from it. The question that arises here is: What rights or legal consequences does (or should) victory in war generate? Medieval writers such as Gratian provide direction here. Gratian and his successors assumed a distinction between just and unjust wars in respect of this matter. As James Brundage explains, they held that 'Property captured and appropriated in a just war was rightfully taken and ... title to it legitimately passed to the victor. ... Rights to tangible property and intangible rights might both be

\footnotetext{
${ }^{54}$ Ken Booth, 'Ten Flaws of Just Wars', The International Journal of Human Rights 4/3 (2000), 316-17.

${ }^{55} \mathrm{As}$ Walzer has remarked, some just war scholars seem to have forgotten that the object of their inquiry is war. Walzer, Just and Unjust Wars, 335-36.

${ }^{56}$ Clausewitz, On War, 579.

${ }^{57}$ Erasmus, The Education of a Christian Prince, ed. by Lisa Jardine (Cambridge: Cambridge University Press 1997), 103.
} 
won in a just war, but not in an unjust war. ${ }^{58}$ Later, in the seventeenth century, legal theorists such as Hugo Grotius and Samuel von Pufendorf would complicate matters even further by inquiring as to whether victory in war created new legal rights for the winning party or merely vindicated preexisting ones. ${ }^{59}$ By engaging the concept of victory, then, scholars may acquire greater traction on questions pertaining to the spoils of just wars, and thus open up a new approach to jus post bellum reasoning.

This brings me to the culmination of my argument. Bringing the concept of victory into play re-connects just war reasoning to its own critical edge by forcing scholars to be 'honest in their just war thinking'. ${ }^{60}$ It does so by compelling these scholars to grapple with the question of what the recourse to war can do for a given society in any particular case and whether it is ever worth the misery it sews. Pitched in these terms, rather than in the gentler discourse of justice and peace (as per Fixdal), or peace, justice and reconciliation (as per Patterson), the gravity of embarking on a just war becomes fully apparent. The scholar, if he or she is so minded, may trial this approach out by asking which if any just wars delivered an incontrovertible victory that was both worthy of the name and worth the toll it exacted. Very few wars, I wager, would pass this test. Accordingly, rather than surrendering just war thinking to a retrograde logic, as critics have suggested, bringing the concept victory more firmly into play would lend it greater stringency and thereby give it a sharper critical edge.

It might of course be objected that this is not an especially radical proposal. There is some truth to this. Even setting aside the debate about 'reasonable chance of success' canvased in Part Two of this article, the principle of jus ad bellum proportionality ostensibly already covers the role earmarked here for victory. The argument here, however, is that if we are serious about proportionality, we must connect it not just to conversations about body-counts or the defence of values, or to effecting a balance between good and harm, but to discussions of the kind of victory we wish to see achieved and their limitations. ${ }^{61}$ This would prevent just war scholars

\footnotetext{
${ }^{58}$ James A. Brundage, 'Holy War and Medieval Lawyers', in Thomas Patrick Murphy (ed.), The Holy War (Columbus, OH: Ohio State University Press 1976), 109.

${ }^{59}$ See: Stephen C. Neff, War and the Law of Nations: A General History (Cambridge: Cambridge University Press 2005), 137-40. Also: Sharon Korman, The Right of Conquest (Oxford: Clarendon Press 1996).

${ }^{60}$ John Howard Yoder, When War is Unjust: Being Honest in Just War Thinking - Revised Edition (Maryknoll, NY: Orbis 1996).

${ }^{61}$ The literature on proportionality mostly ignores the issue of victory. For example, the key paper in the field does not make a single reference to the notion of victory or winning. Thomas Hurka, 'Proportionality in the Morality of War', Philosophy \& Public Affairs 33/1 (2005), 34-46. A later paper by Gary Brown only notes that 'Proportionality does not preclude waging war to win.' Gary D. Brown, 'Proportionality and Just War', Journal of Military Ethics 2/3 (2003), 173. There are of course exceptions. Michael Walzer's statement on proportionality as it applied to the 2008-09 Gaza War is a case in point. Michael Walzer, 'The Gaza War and Proportionality', Dissent Magazine, 8 January 2009. Available at: https://www.dissentmagazine.org/online_articles/the-gaza-war-and-proportional ity. Accessed: 16 July 2017.
} 
from falling into the trap of treating war as a bloodless abstraction and remind them of exactly what is at stake. A stanza from the aforementioned poem by Wilfred Owen, 'Smile, Smile, Smile', illuminates this point: 'Peace would do wrong to our undying dead/The sons we offered might regret they died/If we got nothing lasting in their stead./We must all be solidly indemnified./Though all be worthy Victory which all bought. ${ }^{62}$

An alternative objection is that the motive behind factoring the concept of victory explicitly into moral reflection on war is to undercut the very idea of just war. By highlighting the costs associated with victory and underscoring the probability that any 'victory' achieved will likely be partial at best, it is true that this approach is more rather than less stringent when it comes to sanctioning the recourse to war. This, one might respond, is exactly how it ought to be. But-and it is important to be clear on this point-this approach does not preclude the possibility of just wars. It acknowledges that war may be justified in certain circumstances. It should not, then, be discounted as a form of pacifism-by-the-back-door. Its aim is not to endorse the kind of reasoning that James Turner Johnson has pilloried under the pejorative label jus contra bellum. ${ }^{63}$ Rather it is to encourage just war scholars to bear in mind both the limits of what can be achieved by the use of force in any instance, and the suffering it necessarily brings. As such, it is offered as a means, not only by which just war thinking might be kept honest, but also as a contribution to protecting against what Reinhold Niebuhr described as 'the ironic tendency of virtues to turn into vices when too complacently relied upon; and of power to become vexatious if the wisdom which directs it is trusted too confidently. ${ }^{64}$

\section{Conclusion}

In this essay, I have presented a simple argument that challenges the resistance of modern just war scholars to the concept of victory. While I have acknowledged the (good) reasons why scholars may wish to avoid the notion of victory, I also argue that engaging it would grant them a more direct view of the limitations of just war and what it can achieve in any given instance. As such, taking victory into account would remind them of the well-worn adage that 'just war is just war', and the importance of always remembering this when making judgements about the rights and wrongs of the use of force. There is, however, a twist here. Where most scholars who invoke the idea that 'just war is just war' do so in a bid to discredit the whole enterprise of just war thinking, my

\footnotetext{
${ }^{62}$ Wilfred Owen, 'Smile, Smile' Smile', in Anthem for Doomed Youth (London: Penguin 2015), 17.

${ }^{63}$ James Turner Johnson, 'The Broken Tradition', The National Interest 45 (1996), 28. Also: Serena K. Sharma, 'The Legacy of Jus Contra Bellum: Echoes of Pacifism in Contemporary Just War Thought', Journal of Military Ethics 8/3 (2009), 217-30.

${ }^{64}$ Reinhold Niebuhr, The Irony of American History (Chicago: University of Chicago Press 2008), 133.
} 
conclusion is that it is rather the basis upon which that enterprise properly rests. ${ }^{65}$ For it is only by keeping in mind the base realities of the 'war' in 'just war' that just war scholars can hope to make the right calls and reach the right judgements. The irony of this is that the incorporation of victory into just war deliberations will thus render it a less rather than more triumphalist discourse, and, conversely, a more rather than less critical resource.

There is, however, another side to this argument that I have so far avoided. This is the idea that if just war scholars will find their efforts enriched by the language of victory, scholars interested in victory might similarly benefit from tapping into the bank of ideas supplied by the just war tradition. By connecting the examination of victory to the principles of justice, peace and order that animate the just war tradition, scholars in this field may discover new ways of thinking about what has hitherto been cast in terms of a relation between 'military victory' and 'political victory'. ${ }^{66}$ This, however, is a task for another day. In the meantime, it is appropriate to conclude on the sombre note struck by events in Mosul, where the Iraqi army's victory over the Islamic State has recently turned vicious. ${ }^{67}$ Lamentably, these dismal developments underscore both the gravity and urgency of the matters discussed in this essay.

\section{Acknowledgments}

I would like to thank the following people for their help with this paper: Sophia Dingli, Anders Engberg Pederson, Chiara de Franco, Naomi Head, Andrew Hom, Phil O'Brien and Ty Solomon.

\section{Disclosure statement}

No potential conflict of interest was reported by the author.

\section{Funding}

Research for this paper was generously supported by the ESRC [ES/L013363/1].

\section{Notes on contributor}

Cian O'Driscoll is a senior lecturer in Politics at the University of Glasgow. He is interested in the ethics of war, and in particular the just war tradition, and has

\footnotetext{
${ }^{65}$ This is indeed how Booth (fn. 54) invokes it.

${ }^{66}$ Beatrice Heuser has already proposed something of this character, but the work remains to be done. Heuser, 'The Neglected Trinity'.

${ }^{67} J o h n$ Emery, "'Victory" in Mosul: Fighting Well and the Horrors of "Winning"'. At: https://www. ethicsandinternationalaffairs.org/2017/victory-mosul-fighting-well-horrors-winning/. Accessed: 20 August 2017.
} 
published widely in this area. He currently has a monograph entitled "Victory: The Triumph and Tragedy of Just War" forthcoming with Oxford University Press. He is the Chair of the International Ethics section of the International Studies Association.

\section{Bibliography}

Alger, John I., The Quest for Victory: The History of the Principles of War (Westport, CT: Greenwood Press 1982).

Allman, Mark J. and Tobias L. Winwright, After the Smoke Clears: The Just War Tradition and Post War Justice (Maryknoll, NY: Orbis 2010).

Angstrom, Jan., 'The United States Perspective on Victory in the War on Terrorism', in Jan Angstrom and Isabelle Duvesteyn (eds.), Understanding Victory and Defeat in Contemporary War (Abingdon: Routledge 2007), 94-113.

Aristotle, Nicomachean Ethics, trans. by Harris Rackham (London: Wordsworth Classics 1996).

Augustine, Saint., City of God against the Pagans, ed. by R. W. Dyson (Cambridge: Cambridge University Press 1998).

Bass, Gary., 'Jus Post Bellum', Philosophy \& Public Affairs 32/4 (2004), 384-412. doi:10.1111/j.1088-4963.2004.00019.x

Bellamy, Alex J., 'The Responsibilities of Victory: Jus Post Bellum and the Just War', Review of International Studies 34 (2008), 601-25. doi:10.1017/S026021050800819X

Blanken, Leo J., Hy Rothstein, and Jason J. Lepore (eds.), Assessing War: The Challenge of Measuring Success and Failure (Washington, DC: Georgetown University Press 2015).

Blum, Gabriella., 'The Fog of Victory', European Journal of International Law 24/1 (2013), 391-421. doi:10.1093/ejil/cht008

Bond, Brian., The Pursuit of Victory: From Napoleon to Saddam Hussein (Oxford: Oxford University Press 1996).

Booth, Ken., 'Ten Flaws of Just Wars', The International Journal of Human Rights 4/3 (2000), 1-23. doi:10.1080/13642980008406890

Brown, Gary D., 'Proportionality and Just War', Journal of Military Ethics 2/3 (2003), 171-85. doi:10.1080/15027570310000667

Brundage, James A., 'Holy War and Medieval Lawyers', in Thomas Patrick Murphy (ed.), The Holy War (Columbus: Ohio State University Press 1976), 99-140.

Brunstetter, Daniel and Cian O'Driscoll (eds.), Just War Thinkers: From Cicero to the 21st Century (Abingdon: Routledge 2018).

Bush, George W. President, 'President Bush Announces Major Combat Operations in Iraq Have Ended'. 1 May 2003. Available at: https://georgewbush-whitehouse. archives.gov/news/releases/2003/05/20030501-15.html. Accessed 16 Jul. 2017.

Churchill, Winston., The World Crisis, Volume V: The Unknown War (London: Bloomsbury 2015).

Cicero, Marcus Tullius., The Republic and the Laws, trans. by Niall Rudd (Oxford: Oxford University Press 1998).

Clausewitz, Carl von., On War, ed. by Michael Howard and Peter Paret (Princeton: Princeton University Press 1989).

Cox, Rory., 'Expanding the History of the Just War: The Ethics of War in Ancient Egypt', International Studies Quarterly 61/2 (2017), 371-84. doi:10.1093/isq/sqx009

Dill, Janina (ed.), 'Symposium on Ending Wars', Ethics 125/3 (2015), 627-780. doi:10.1086/679529

Eckert, Amy., Outsourcing War: The Just War Tradition in the Age of Military Privatization (New York: Cornell University Press 2015). 
Emery, John, "'Victory" in Mosul: Fighting Well and the Horrors of "Winning"'. https:// www.ethicsandinternationalaffairs.org/2017/victory-mosul-fighting-well-horrorswinning/. Accessed 20 Aug. 2017.

Erasmus, The Education of a Christian Prince, ed. by Lisa Jardine (Cambridge: Cambridge University Press 1997).

Fiala, Andrew., The Just War Myth: The Moral Illusions of War (Lanham, MD: Rowman \& Littlefield 2008).

Finlay, Christopher J., Is Just War Possible? (Cambridge: Polity 2018).

Fixdal, Mona., Just Peace: How Wars Should End (New York: Palgrave 2012).

Franks, Tommy General, 'The Meaning of Victory: A Conversation with Tommy Franks', The National Interest 86 (Nov. 2006), 8.

Gray, Colin S. and Keith Payne, 'Victory is Possible', Foreign Policy 39 (1980), 14-27. doi:10.2307/1148409

Gross, Michael L. and Tamar Meisels (eds.), Soft War: The Ethics of Unarmed Conflict (Cambridge: Cambridge University Press 2017).

Heuser, Beatrice., 'Victory, Peace, and Justice: The Neglected Trinity', Joint Forces Quarterly 69 (2013), 1-7.

Hobbs, Richard., The Myth of Victory: What Is Victory in War? (Boulder, CO: Westview 1979). Hom, Andrew R. and Cian O'Driscoll, 'Can't Lose for Winning: Victory in the Trump Presidency', The Disorder of Things Blogspot, 24 Jan. 2017. Available at: https:// thedisorderofthings.com/2017/01/24/cant-lose-for-winning-victory-in-the-trumppresidency/. Accessed 16 Jul. 2017.

Hurka, Thomas., 'Proportionality in the Morality of War', Philosophy \& Public Affairs 33/ 1 (2005), 34-46. doi:10.1111/j.1088-4963.2005.00024.x

Inbar, Efraim and Eitan Shamir, "'Mowing the Grass": Israel's Strategy for Protracted Intractable Conflict', Journal of Strategic Studies 37/1 (2014), 65-90. doi:10.1080/ 01402390.2013 .830972

Johnson, Dominic P. and Dominic Tierney, Failing to Win: Perceptions of Victory and Defeat in International Politics (Cambridge, MA: Harvard University Press 2006).

Johnson, James Turner, 'The Broken Tradition', The National Interest 45 (1996), 27-36. Johnson, James Turner, Morality and Contemporary Warfare (New Haven: Yale University Press 1999).

Junger, Sebastian., War (New York: Twelve 2011).

Klay, Phil., Redeployment (New York: Penguin 2014).

Korman, Sharon., The Right of Conquest (Oxford: Clarendon Press 1996).

Lucas, George R., Ethics and Cyber Warfare: The Quest for Responsible Security in the Age of Digital Warfare (Oxford: Oxford University Press 2017).

MacArthur, Douglas General, 'Farewell Address to Congress, 19th April, 1951'. Available at: http://www.americanrhetoric.com/speeches/douglasmacarthurfare welladdress.htm. Accessed 16 Jul. 2017.

Mandel, Robert., The Meaning of Military Victory (Boulder, CO: Lynne Rienner 2006).

Mandel, Robert., 'Defining Postwar Victory', in Jan Angstrom and Isabelle Duvesteyn (eds.), Understanding Victory and Defeat in Contemporary War (Abingdon: Routledge 2007), 13-45.

Mandelbaum, Michael., Mission Failure: America and the World in the Post-Cold War Era (Oxford: Oxford University Press 2016).

Martel, William C., Victory in War: Foundations of Modern Military Policy (Cambridge: Cambridge University Press 2007).

May, Larry., After War Ends: A Philosophical Perspective (Cambridge: Cambridge University Press 2012). 
McNeilly, Mark R., Sun Tzu and the Art of Modern Warfare (Oxford: Oxford University Press 2015).

Neff, Stephen C., War and the Law of Nations: A General History (Cambridge: Cambridge University Press 2005).

Niebuhr, Reinhold., The Irony of American History (Chicago: University of Chicago Press 2008).

O'Driscoll, Cian, 'At All Costs and in Spite of All Terror? the Victory of Just War', Review of International Studies 41 (2015), 799-811. doi:10.1017/S0260210515000042

O'Driscoll, Cian and Andrew R. Hom, 'Introduction', in Andrew R. Hom, Cian O'Driscoll, and Kurt Mills (eds.), Moral Victories: The Ethics of Winning Wars (Oxford: Oxford University Press 2017), 1-14.

Orend, Brian., 'Jus Post Bellum', Journal of Social Philosophy 31/1 (2000), 117-37. doi:10.1111/0047-2786.00034

Owen, Wilfred., Anthem for Doomed Youth (London: Penguin 2015).

Patterson, Eric D., Ending Wars Well: Order, Justice, and Conciliation in Contemporary Post-Conflict (New Haven, CT: Yale University Press 2012).

Patterson, Eric D. (ed.), Ethics Beyond War's End (Washington, DC: Georgetown University Press 2012).

Pattison, James., Just and Unjust Alternatives to War (Oxford: Oxford University Press 2018).

Record, Jeffrey., Hollow Victory: A Contrary View of the Gulf War (Washington, DC: Brassey's 1993).

Reet, Brian van., Spoils (London: Jonathan Cape 2017).

Robinson, Paul, Nigel de Lee, and Don Carrick (eds.), Ethics Education in the Military (Burlington, VT: Ashgate 2008).

Rodin, David., 'Two Emerging Issues of Jus Post Bellum: War Termination and the Liabilities of Soldiers for Crimes of Aggression', in Carsten Stahn and Jan K. Kleffner (eds.), Jus Post Bellum: Towards a Law of Transition from Conflict to Peace (The Hague: TMC Asser Press 2008), 53-77.

Rose, Gideon., How Wars End: Why We Always Fight the Last Battle (New York: Simon \& Schuster 2011).

Schuck, Michael J., 'When the Shooting Stops: Missing Elements in Just War Theory', Christian Century, 26 Oct. 1994, pp. 982-83.

Sharma, Serena., 'The Legacy of Jus Contra Bellum: Echoes of Pacifism in Contemporary Just War Thought', Journal of Military Ethics 8/3 (2009), 217-30. doi:10.1080/15027570903230281

Tierney, Dominic., The Right Way to Lose a War: America in an Age of Unwinnable Conflicts (New York: Little, Brown and Company 2015).

Totten, Mark., First Strike: America, Terrorism, and Moral Tradition (New Haven: Yale University Press 2010).

Tran, Mark, 'General David Petraeus Warns of Long Struggle Ahead for US in Iraq', Guardian, 11 Sept. 2008. Available at: https://www.theguardian.com/world/2008/ sep/11/iraq.usa. Accessed 16 Jul. 2017.

Waltz, Kenneth., Man, the State and War: A Theoretical Analysis (New York: Columbia University Press 2001).

Walzer, Michael, (ed.), 'The Triumph of Just War Theory (And the Dangers of Success)', in Arguing About War (New Haven, CT: Yale University Press 2003), 3-22.

Walzer, Michael, 'The Gaza War and Proportionality', Dissent Magazine, 8 Jan. 2009. Available at: https://www.dissentmagazine.org/online_articles/the-gaza-war-andproportionality. Accessed 16 Jul. 2017. 
Walzer, Michael., 'The Aftermath of War: Reflections on Jus Post Bellum', in Eric D. Patterson (ed.), Ethics Beyond War's End (Washington, DC: Georgetown University Press 2012), 35-46.

Walzer, Michael, Just and Unjust Wars: A Moral Argument with Historical Illustrations $5^{\text {th }}$ edition (New York: Basic Books 2015).

Weigley, Russell F., The Age of Battles: The Quest for Decisive Warfare from Breitenfeld to Waterloo (London: Pimlico 1991).

Weinberger, Caspar, 'The Uses of Military Power'. Available at: http://www.pbs.org/ wgbh/pages/frontline/shows/military/force/weinberger.html. Accessed 28 May 2015.

Wynn, Phillip., Augustine on War and Military Service (Minneapolis: Fortress Press 2013).

Yoder, John Howard, When War is Unjust: Being Honest in Just War Thinking - Revised Edition (Maryknoll, NY: Orbis 1996). 